\title{
Intellectual foundations of public choice, the forest from the trees
}

\author{
Roger D. Congleton ${ }^{1}$
}

Received: 27 March 2018 / Accepted: 10 April 2018 / Published online: 2 May 2018

(C) Springer Science+Business Media, LLC, part of Springer Nature 2018

\begin{abstract}
After War World II, a group of scholars began using rational choice models from economics and game theory to examine the manner in which public policies would be determined if men and women were as "rational" in their political activities as they were in other spheres of life. The implications of such an approach to politics were not obvious and took decades to be worked out. Indeed, they are still being worked out. The result was a new field of research that deepened our understanding of economic and political systems and their many interdependencies. This review essay provides an overview of the core findings of public choice during its first half century and of the boot-strapping process through which those findings emerged. Those core findings provide the idea base and results that ground most contemporary public choice research.
\end{abstract}

Keywords Public choice $\cdot$ Science as a spontaneous order $\cdot$ Bootstrapping · Methodology $\cdot$ Key results · Theory of elections · Theory of interest groups · Constitutional political economy

JEL Classification $\quad \mathrm{B} 2 \cdot \mathrm{D} 7 \cdot \mathrm{H} 1$

\section{Introduction}

This paper provides a short overview of the intellectual foundations of public choice. There are a number of ways one could do this. For example, such a paper could recount key developments in political theory that echo throughout the public choice literature. Plato raised concerns about political agency problems in The Republic. Aristotle's Politics reviewed properties of alternative forms of government, including democracy, aristocracy and dictatorship, noting advantages and disadvantages that each might have and making a case for

Roger D. Congleton

roger.congleton@mail.wvu.edu

1 BB\&T Professor of Economics, West Virginia University, Morgantown, WV, USA 
representative democracy as the most robust and, in many ways, the most just form of governance. From there, one could skip forward to Hobbes and Locke with their contractarian theories of the state and analysis of the limits of just authority, or to Montesquieu's Spirit of the Law, which discusses advantages of federal and divided systems of government. Then, one could focus on the Federalist, which discuss in detail how a particular form of "checks and balances", together with political competition, can induce good government or at least avoid bad government - a form of institutionally induced equilibrium. All these are ideas associated with contemporary public choice research.

Alternatively, one could stress the precursors to contemporary rational choice theory. One might begin with Borda and Condorcet's rational choice-based analysis of alternative voting rules in the period just before the French Revolution. Then, one could review ideas about alternative voting rules (sometimes denigrated as the "fancy franchise") worked out by practical politicians in Northern Europe during the late nineteenth century as well as political theorists such Thomas Hare, Victor D'Hondt and Charles Dodgson (Lewis Carroll) during a period in which constitutional reforms were widely contemplated and undertaken in Europe. ${ }^{1}$

Another approach would be to leap forward to the period around World War II to identify and study the teachers of Duncan Black, Kenneth Arrow, James Buchanan, Anthony Downs, William Riker, Gordon Tullock, Mancur Olson and William Niskanen, who might be said to be the indirect sources of - or catalysts for-many of the ideas that public choice scholars have focused on for the past half century. Johnson (2014, 2018 forthcoming), for example, provides an overview of the influences of Henry Simons on James Buchanan.

Instead, I'll explore another natural meaning of the intellectual foundations of public choice research, namely the common idea base that public choice scholars use as a point of departure when engaging in research. These intellectual foundations of public choice were sketched out by the first and second generations of scholars as they invented the rational choice model-based analysis of politics and began exploring its many implications. Their innovations, in turn, were extended and revised in many ways by the third, fourth and fifth generations of public choice scholars. It is these later scholars that truly produced the field called public choice - and many of these scholars also added significantly to its intellectual foundations.

A few fine books and papers do not create a field, although they may initiate one. Without the research that followed, the field of public choice would not have emerged. No great outpouring of rational choice politics followed Condorcet and Borda. No grand theory of electoral methods followed Hare, D'Hondt and Dodgson. An idea may be articulated, a row may be hoed and planted, but a field of research cannot be established and plowed over without the sustained efforts of hundreds of researchers.

An implication of this approach is that a field of research is not determined by its foundations but rather produces them. It is not a superstructure erected on stable piers and footings, as a building is, but is largely in contact with the soil at every point, as new roots are put down and old ones expanded. A field of research is a complex ecology of ideas, interests, results and scholarship.

It is the complementarities among scholars working in a field that define it. In public choice research, those complementarities are partly generated by its methodology and partly by its intellectual foundations - the most broadly known and accepted findings of

${ }^{1}$ See, for example, McLean and Hewitt (1994) or McLean (1995). 
the field. Those engaged in the research project that came to be called public choice may not have been fully conscious of the complementarities among their research interests, but nonetheless such complementarities allowed public choice scholars to produce a far more dense and connected body of knowledge than an equally creative and diligent group of scholars could have generated without such complementarities.

With these propositions in mind, this short essay is organized into a series of brief overviews of the three main strands of public choice research: elections, interest groups and constitutions. The overviews discuss a subfield's founding, its early development, and some of the best-known findings. Each emphasizes the bootstrapping that took place as public choice emerged as a field of study. The paper concludes with a short overview of the major complementarities among the three research programs-which helps explain why they are all part of the same area of study.

\section{A short digression on the methodology of public choice research}

Before starting the overview of the common knowledge base of public choice, it is useful to discuss briefly the main methodology of public choice scholarship. It is from that methodology that most of its novel results emerged.

At the heart of the public choice methodology is the hypothesis that the adults participating in politics have interests that they try to advance through political activities. Their interests usually are taken to be narrow ones that are essentially fixed by the time adulthood is reached. The feasible set of actions that might be taken to advance those interests is jointly determined by the technologies of their era; their talents, skill and knowledge; and the laws that create, encourage or discourage various possibilities.

For the most part, public choice scholarship takes self-interest, talent and technology as given - as unalterable and constant during the period of analysis - and focuses on the effects of what might be called choice settings. The choice settings of greatest interest are ones associated with an individual's political institutions and place within them. For example, an individual outside government can cast votes in a democracy. An elective official, but not voters, can participate directly in the selection of new laws. Government employees, rather than voters or legislators, are charged with administering the laws adopted, and always have some discretion over how those laws will be implemented. They also have the ability to recommend policies to the legislature. A member of a politically active interest group may work more or less energetically to advance the shared interests of his or her group. They may attempt to induce voters, legislators or bureaucrats to take their advice into account when casting votes, choosing policies and implementing them.

The three main fields of public choice rely upon the same characterization of human nature, but focus on different political choice settings. Public choice research focuses for the most part on choices in settings that affect voting, interest group activities and the selection of political institutions. Within those choice settings, the individuals modeled all attempt to advance their self-interests, which usually but not always are narrowly defined. The choice setting determines what is possible.

The public choice research program differs from earlier interest-based analyses of politics by (1) its use of mathematical models to characterize individual choice settings; (2) its insistence that the interests of adults are essentially set in stone; (3) its methodological insistence that all the implications of a "good" model are to be taken seriously, even in cases where initially little or no empirical evidence supports them; (4) its use of linear 
regression and experimental tests of the implications of those models; and (5) its continual efforts to improve the models, data and statistical methods used.

Most model builders tend to use relatively narrow characterizations of individual interests-reflecting the aesthetics of Occam's razor and the relative ease with which such models can be constructed-but broader notions of self-interest occasionally are adopted that include such considerations as ideology, religion, fairness, trust and ethics. The methodology came to be called the rational choice approach to politics and, perhaps surprisingly, provided a broad range of new insights about how political systems operate.

The rational choice approach to politics produced a long series of new puzzles to be tackled, some of which focus on methodological issues, but most of which gradually produced a deeper understanding of politics and political institutions-one comparable to that of mainstream political science. The results also deepened our understanding of interdependencies between political and economic systems. For example, that constitutions have significant effects on the public policies adopted implies that economic development is partly determined by a nation or region's political institutions, because the regulatory and tax decisions of governments have significant impacts on the extent and rate of economic development.

It is the core results - the mainstream or idea base of public choice - that can be said to provide the intellectual foundations of public choice. They provide points of departure for subsequent research projects, many of which would never have been imagined without that base. That grounding collection of models and results is the focus of this essay.

Public choice scholarship also is known for its many innovative "edge" and "applied' research projects, which unfortunately cannot be covered in a short essay. Those contributions explore what "self-interest" consists of, differences among de jure and de facto institutions, the motivation and effects of coalition formation, open and underground markets, the origins and evolution of governments, normative concepts that can be used to evaluate regulations, laws and constitutions, and so forth. ${ }^{2}$ Hundreds of empirical studies have been undertaken to assess the extent to which public choice models and ideas can account for a wide range of public policies in a broad range of national and local governments. Many of these research projects are important in their own right and have affected the grounding ideas of the public choice research program as they were adjusted a bit to take account of the new ideas, puzzles and results.

The remainder of this short overview focuses on the core findings of the first half century of public choice research. That era of research established its grounding ideas-ideas that will doubtless be refined further as the field progresses, but which still provide points of departure for most contemporary public choice research. ${ }^{3}$

\footnotetext{
${ }^{2}$ Examples include Riker's theory of coalition formation; Niskanen's analysis of bureaucratic incentives; Cramer's analysis of political business cycles; Tullock's and Kuran's theories of revolution; Wintrobe's typography of dictatorship; Buchanan's, Ostrom's and Riker's work on political philosophy and methodology; Frey's work on happiness and politics; Bram's work on fairness; Vanberg's work on social evolution; Buchanan's and Frey's work on human nature; Congleton's analysis of the rise of Western democracy; and Tollison's and Ekelund's analysis of the Catholic Church, to name just a few.

3 Although this essay might serve as a useful introduction to the field, far more thorough book-length surveys are also available. See, for example, Mueller (2003) or Congleton et al. (2018, forthcoming).
} 


\section{Emergence of the three main research programs of public choice}

\subsection{Election theory}

Duncan Black's 1948 paper launched the public choice literature. His analysis of voting in small groups includes no references to earlier works from political theory. He simply analyzed how utility-maximizing voters would cast their votes and how those votes would determine a committee's choices when they are made using majority rule. Several major insights emerged from his analysis. He noted the tendency of committee votes to settle on the proposal most preferred by its median voter. He noted the possibility of majoritarian cycles - cases in which every possible proposal may be defeated by another-and conditions under which cycling would not occur, namely committees in which all voters had single-peaked preferences. In cases in which no single policy dominates all others, the results from any finite set of motions, he argued, tend to be random.

Notice the challenge that his relatively simple technical paper presents to those who had taken democracy and majority rule to be the best of all political systems. Insofar as a country's legislature can be regarded as a committee, the policies that emerge when legislators' preferences are all single peaked tend to be those of the median legislator. Public policies are not products of discussion or reasoned debate but the policy preferences that legislators had in their minds when the debates began. The median voter is not especially wise, but simply pivotal in all close votes. It is his or her position in the middle of legislator policy preferences, rather than his or her debating skills or intelligence, that allows the median voter to determine public policy.

And, this is the very best thing that could happen! Otherwise, democratic policies tend to be random, reflecting the time constraints of the electoral cycle and the series of votes undertaken. After Black's (1948) classic paper, it could no longer be taken for granted that democracies produce the very best public policies through some kind of general or collective will.

Black's analysis also demonstrated that rational choice models could be used to think about voting and that doing so can produce new insights about the outcomes of majority decision-making. Together, his results and methodology would stimulate a long series of research papers and books about how democracy functions when men and women are as rational and self-interested as voters as they are as consumers or producers. Arrow (1951/2012) generalized Black's most unsettling result, demonstrating that neither a clear outcome nor a consistent aggregate preference ordering can be assured by any nondictatorial decision rule for all possible distributions of voter preferences. His "impossibility theorem" was the first of several contributions that led to his Nobel Prize in 1972.

Downs (1957) generalized Black's median voter result, noting that pragmatic twoparty competition for votes tends to generate nearly identical platforms at or near the ideal point of the median voter. Downs also noted another problem with majoritarian outcomes, namely that voters have only very weak incentives to be well informed about public policies. Rational voters are inclined to remain ignorant of many, perhaps most, policy and electoral details. The marginal cost of acquiring and procession information about candidates, platforms and the likely consequences of alternative public policies tends to be far higher than their expected benefits.

Second- and third-generation scholars continued exploring the issues raised by those three pioneers of rational-choice-based election theory. For example, Plott (1967) characterized general symmetry conditions for voter preferences that are sufficient for the 
existence of a median or moderate voter equilibrium under majority rule. McKelvey (1976) demonstrated that a person who controls the sequence of alternatives brought before a committee or legislature potentially can reach any policy outcome he or she wants under majority rule when voter preferences do not satisfy the Plott conditions. The effects of rational ignorance were linked to the older idea of fiscal illusion and possible mistakes associated with majoritarian outcomes by Wagner (1976) and others.

In response to the rational ignorance and fiscal illusion concepts, a new line of research was established on the extent to which majority rule might yield more accurate decisions than implied by the information held by any single voter in mass elections in which voters cannot be presumed to communicate with each other and pool their knowledge. That literature demonstrated that, even though every voter tends to be error-prone because of limited information (but right more than half the time), Condorcet's Jury Theorem implies that far better (more accurate) decisions are reached in general elections than one might expect. Indeed, that conclusion may account for the success of democratic polities (Grofman et al. 1983; Grofman and Owen 1986).

Some 30 years after Black's (1948) groundbreaking paper, Tullock (1981) asked the readers of the journal Public Choice why Western democracies have such stable public policies given the likelihood of majority cycles. One answer was provided by Shepsle and Weingast $(1981,1987)$, who suggested that the micro-institutions of legislatures account for most of the stability in policy making in the West, rather than-or perhaps in addition to - the platforms adopted by legislators to obtain their positions of authority. Another possibility was implied by Poole and Rosenthal (1985), who demonstrated that one or two issue-dimensions can account for most of the voting in the legislatures of the United States - the narrower the dimensionality of the issue space, the more likely it is that a median voter exists. Another possibility is that voters cannot always identify exactly what option is precisely best and so vote probabilistically. Oddly enough, if voters are only roughly able to assess their interests - rather than fully able to do so-electoral competition in multiple dimensions tends to be more stable, and both majority and minority interests tend to be taken into account by the winning candidates and parties-who again usually converge to moderate platforms. What came to be called stochastic voter models are more likely to have stable and attractive electoral equilibria than deterministic models (Coughlin and Nitzan 1981). ${ }^{4}$

These new ideas, in turn, induced additional efforts to generalize earlier results, probe for new weaknesses, and undertake statistical and experimental tests of their implications. Voters might, for example, care about characteristics of candidates other than their proposed policies (Ansolabehere and Snyder 2000) or may vote for expressive rather than instrumental purposes (Brennan and Hamlin 1998). The rational-choice-based election literature deepened and expanded with such efforts. It was the most active of the three fields of public choice research during its first three decades.

It bears noting how different public choice models of electoral politics were from mainstream political science at that time. They were deductive rather than inductive. They tended to use regression analysis and experiments to test propositions, rather than other methodologies. They tended to use data based on actual outcomes, rather than surveys. They identified problems with democratic decision-making and possible solutions to those problems that had passed almost entirely unnoticed in mainstream research.

${ }^{4}$ Exceptions to this rule are noted in Enelow and Hinich (1981) and Kirchgässner (2000). 
Table 1 Public choice theory of elections: a sample of influential pieces

Black, D. (1948). On the rationale of group decision-making. Journal of Political Economy, 56(1),

2586 23-34

Arrow, K. J. (1951/2012). Social choice and individual values. New Haven, CT: Yale University

17,832

Press

Downs, A. (1957). An economic theory of democracy. New York, NY: Harper and Row

Plott, C. R. (1967). A notion of equilibrium and its possibility under majority rule. The American Economic Review, 57(4), 787-806

McKelvey, R. D. (1976). Intransitivities in multidimensional voting models and some implications

for agenda control. Journal of Economic Theory, 12(3), 472-482

Tullock, G. (1981). Why so much stability? Public Choice, 37(2), 189-204

Shepsle, K. A., \& Weingast, B. R. (1981). Structure-induced equilibrium and legislative

Enelow, J., \& Hinich, M. J. (1981). A new approach to voter uncertainty in the Downsian spatial model. American Journal of Political Science, 25(3), 483-493

Grofman, B., Owen, G., \& Feld, S. L. (1983). Thirteen theorems in search of the truth. Theory and Decision, 15(3), 261-278.

Poole, K. T., \& Rosenthal, H. (1985). A spatial model for legislative roll call analysis. American Journal of Political Science, 29(2), 357-384

Total citations

Table 1 lists the Google citations for a subset of the pieces mentioned above, not all of which were selected because of their high citation counts. The point of the table is not to document the impact of the papers included, but to point out indirectly the huge number of papers that are not listed by name. Even a dozen good papers and books do not create a field; it is the hundreds or thousands of papers stimulated by them and subsequent insights that that do-what Kuhn (1962) refers to as "normal science". The papers mentioned are simply among the taller trees and bushes in the areas of public choice analyzing elections and electorally driven public policy.

\subsection{Interest groups and public policy}

Nearly 20 years after Duncan Black's article on voting, Mancur Olson (1965) published a book based on his dissertation, the Logic of Collective Action. The book took the public goods concept that had emerged in economics in the previous decade and applied it to group action. It noted that "public goods" or "free rider" problems are associated with all manner of collective action. However, Olson focused most of his attention on the political efforts of such groups. Members of large groups are nearly always better off free riding than participating in a group's costly activities to change public policies. They hope to benefit from the efforts of others, without bearing any of the costs of collective action. Thus, in the absence of an organization, large groups are very unlikely to be politically or otherwise active. Only small groups with relatively strong interests are likely to be politically active.

Whenever lobbying activities alter public policies, public policies tend to favor small, highly motivated interest groups with narrow rather than general interests-at least at the margin. The Logic includes several references to political theorists who wrote about interest groups, but Olson's assessment of past work on interest groups normally is critical. For example, he notes that both Marx and Parsons neglected the free-rider problems associated with collective action and so greatly overstated the influence of large unorganized groups. 
Stigler (1971) took Olson's logic to its natural extreme and argued that economic regulations did not tend to bind industry and limit their profits as often argued, but rather tends to limit competition, impede entry and increase industry profits. Firms have narrow and strong interests relative to their consumers-except perhaps in markets for intermediate goods - and so tend to have their way on regulations and other laws. This conclusion was softened by Peltzman (1976) and Becker (1983), but their papers also implied that firms largely got the regulations they wanted rather than the ones-if any-for which consumers might wish.

From the interest group perspective, economic regulations largely reflect efforts by firms that were termed rent-seeking by Anne Krueger (1974). They redistribute and reduce the net benefits from exchange rather than increase them. Gordon Tullock $(1967,1980)$ pointed out that efforts to obtain such rents are competitive and that the extent of resources invested in such contests is often nontrivial. He argued that these counterproductive investments should be counted as a social loss from rent-seeking. Such "investments" are used to reduce social welfare, rather than to increase it as measured by the aggregate net benefits of their associated economic and political activities. Together, the problems of collective action and losses from rent-seeking can produce substantial drags on economic development (Olson 1982).

A long series of theoretical and empirical research projects followed those thoughtprovoking theories and case studies. Rent-seeking concepts were integrated into models of international trade restrictions (Hillman 1982) and used to explore the extent to which institutions might evolve to mitigate such losses (Congleton 1980). The effects that alternative contest designs and interests have on losses from rent-seeking contests were explored in a long series of theoretical papers by, for example, van Long and Vousden (1987) and Nitzan (1991). Murphy, Shleifer \& Vishny (1993) discuss a broad range of effects that rent seeking can have on economic development in general. Several efforts to estimate the extent of losses from rent seeking also were undertaken using estimation strategies based on Krueger (1974). For example, Cowling and Mueller (1978) estimated losses from resources invested in rent seeking by monopolists in the United Kingdom and the United States. Laband and Sophocleus (1992) estimated losses from all conflicts over real resources in the United States. Losses from rentseeking activities were found to be substantial even in developed countries.

McChesney (1987) pointed out that opportunities for politicians and regulators to benefit from the creation and extraction of rents may also affect the details of public policy and regulation. Such efforts, in turn, may induce a good deal of economic activity to shift among countries or become part of the underground economy where regulations and taxes can be avoided (Schneider and Enste 2000). A wide variety of regulations and tax exemptions in all parts of the world can be accounted for as instances of successful rent seeking or rent extraction (Congleton and Hillman 2015).

Table 2 lists a subset of the articles mentioned above and their Google citations. These articles and books again were not entirely chosen for their citation counts, but for their contributions to the public choice research program on interest groups. The citations again provide evidence of both the influence of this research program and the large number of scholars participating in it. Hundreds of scholars have investigated the extent to which interest groups have had their way on public policies and the extent of the losses generated by their efforts. Kuhn's (1962) normal science had found another fertile pasture. 
Table 2 Public choice theory of interest groups: a sample of influential pieces

Olson, M. (1965). The logic of collective action. Cambridge, MA: Harvard University Press

Tullock, G. The welfare costs of tariffs, monopolies, and theft. Economic Inquiry 5(3), 224-232

Stigler, G. J. (1971). The theory of economic regulation. The Bell Journal of Economics and Man- $\quad 11,988$ agement Science, 2(Spring), 3-21

Krueger, A. O. (1974). The political economy of the rent-seeking society. The American Economic 7673 Review, 64(3), 291-303

Cowling, K., \& Mueller, D. C. (1978). The social costs of monopoly power. The Economic Journal, 88(352), 727-748

Tullock, G. (1980). Efficient rent seeking. In J. M. Buchanan, R. D. Tollison, \& G. Tullock (1980). Toward a theory of the rent-seeking society. College Station, TX: Texas A \& M University Press

Hillman, A. L. (1982). Declining industries and political-support, protectionist motives. The American Economic Review, 72(5), 1180-1187

Nitzan, S. (1991). Collective rent dissipation. The Economic Journal, 101(409), 1522-1534

Schneider, F., \& Enste, D. H. (2000). Shadow economies: size, causes, and consequences. Journal of Economic Literature, 38(1), 77-114

Total citations

\subsection{Constitutional economics}

If one regards governments to be organizations with longer lives than their leaderships, then the rules by which leaders are chosen and decisions are made must partly determine an organization's choices and relative success. Such rules, as implied by Olson's (1965) analysis, are what make a group an organization. The committee models of Duncan Black demonstrated that majoritarian decision-making - a characteristic of decision-making at multiple levels in many organizations and all democratic governments-has clear effects on outcomes. Constitutional economics can thus be said to be a generalization of Black's and Olson's insights. However, this field of research was launched in a somewhat roundabout way that largely was independent of the electoral and interest group research programs.

James Buchanan's (1949) paper on the pure theory of government finance is arguably where the public choice literature on constitutional economics begins, although that was not obvious at the time. It compares two notions of government-organic and individualistic - and makes a case for considering governments to be organizations of individuals, rather than single entities with their own goals and authorities. If governments are to be treated as organized groups of individuals, the manner in which they are organized and the procedures through which decisions are made must be analyzed to understand how public policies emerge. After all, a government's standing procedures and constraints are common determinants for each of its policies.

In a series of papers written during the 1950s, Buchanan gradually concludes that ideal public policies are those that would be unanimously agreed to (Buchanan 1959). It took another step to realize that the same logic applied to the selection of the procedures and constraints for governmental decision-making. That last step likely was catalyzed by a working paper written by Tullock while a visitor at the University of Virginia that analyzed the relative merits of alternative voting rules from the perspective of the individuals using those rules. The result was a book written by both men (Buchanan and Tullock 1962), The Calculus of Consent, which explores the properties of institutions similar to those of the 
United States with an eye to understanding how the various parts affect policy decisions and also to understanding why individuals might agree to use such institutions for the purposes of selecting public policies.

The Calculus explores the effects of voting rules, bicameralism and federalism; and it analyzes their relative merits from the perspective of typical members of the polity of interest. The authors note that majority rule is only one of many possible voting rules and argue that the optimal rule varies with the public policy under consideration. Supermajority rules, for example, are useful ways to protect minority interests when major decisions are being made, as when constitutions are being amended. Federalism and bicameralism may be attractive institutions in part because they have effects similar to supermajority rule, without as strong a bias in favor of the status quo.

Buchanan's writings during the 1950s rarely mentioned the work of political theorists, partly because it was aimed at economists and partly because he does not appear to have been thinking about theories that were general enough to be of interest outside economics. In contrast, the Calculus of Consent was intended to have a broader reach. It includes several chapters on methodological and normative issues and mentions enlightenment scholars such as Hobbes, Locke and Spinoza. Among them, perhaps surprisingly, only Spinoza is given serious attention. (The Calculus does not mention, for example, Aristotle, Plato, Montesquieu, Condorcet, or Mill.) Based on Buchanan's pattern of citations, it appears that Buchanan "backed" into the political theory literature as his thinking evolved in a contractarian direction and his writing began to extend beyond economics. The contractarian normative theory being worked out by Buchanan as an alternative to utilitarian analysis for evaluating both policies and institutions had been dormant since the late eighteenth century.

What political scientists refer to as political theory (and others as political philosophy) had long included discussion of the effects of institutions on political choices, but the rational choice approach provided insights and raised questions that were almost completely overlooked by the preexisting literature. The insights of the Calculus demonstrated that rational choice models could profitably be used to think about institutions broadly considered.

For the first two decades after it was published, most citations to the Calculus were papers that addressed various institutional issues, rather than analyzed major features of political constitutions. It was cited in studies of the organization of firms, international organizations, fiscal federalism, informal institutions, rule-based monetary policy, debates concerning constitutional amendments and in surveys of political philosophy.

The Calculus of Consent thus stimulated a variety of research projects, although relatively little on political constitutions themselves. Although constitutional analysis itself was not entirely ignored during the next three decades - Rae (1969), Mueller (1973, 1996) and Nitzan and Paroush (1982), for example, explored constitutional and theoretical issues raised by the Calculus - it was not a rapidly developing area of research. In that period, the Calculus was usually cited so that an author could take for granted that institutions mattered and could profitably be examined using rational choice models.

Buchanan (1975) and Buchanan and Brennan (1985/2008) attempted to stimulate further constitutional research by deepening the conceptual foundations of constitutional analysis. Another impulse was provided by Ostrom's (1990) fieldwork which demonstrated that many institutional solutions to local public goods and commons problems exist. Moreover, insofar as institutional solutions to such problems produced similar results, different institutions could stand side-by-side for centuries. A further impulse was provided by work in 
fiscal federalism, as the fiscal effects of small differences in state constitutions were examined within the United States and Switzerland. Small differences in policymaking procedures and constitutional constraints among the states of the United States were shown to affect state fiscal policies, as in Crain and Miller III (1989), von Hagen (1991) and Inman and Rubinfeld (1997). Switzerland provided similar opportunities for comparative analysis with somewhat greater variation in constitutional details among cantons. Those variations also turned out to affect public policies, as shown, for example, by Frey (1994) and Kirchgässner and Pommerehne (1996).

International public choice research on the effects of political constitutions emerged at about the same time, nearly 30 years after the Calculus was written. Grier and Tullock (1989) demonstrated that political institutions affected economic development, Congleton (1992) showed that political institutions affected policy choices, such as environmental policies, and Olson (1993) provided a new theoretical framework that helped explain differences between democracies and dictatorships. Research on the policy effects of national constitutions accelerated after the collapse of the Soviet Union and the sudden need for constitutional advice.

Comparative constitutional research accelerated again in the late 1990s as better international databases emerged with more fine-grained measures of institutions and institutional quality. These were, for example, productively exploited by Knack and Keefer (1995) and Persson, Roland \& Tabellini (2000), who extended the Grier and Tullock (1989) and Congleton (1992) results. Persson and his various coauthors demonstrated that the details of democratic constitutional design mattered. Other empirical research demonstrated that forms of government between dictatorships and democracies had systematically different public policies and rates of economic development than pure democracies and pure dictatorships. ${ }^{5}$ In the 2000s, empirical work on the effects of constitutional design on public policies within the West and worldwide were undertaken by dozens of scholars, many but not all of them members of the two major public choice societies.

The seeds planted by the Calculus of Consent took a long time to blossom. Like the seeds of many long-lived desert plants, constitutional political economy evidently needed several "fires" and a bit of "rain" to germinate. Constitutional political economy has been one of the most active areas of public choice research for the past two decades.

Table 3 lists a subset of the authors, titles, and citations from the pieces mentioned above. It is again intended to demonstrate that scientific development is not the work of a few especially insightful men and women but of dozens of scholars who find a particular area of research interesting and fruitful, many of whom have never read the classic works. If each citing scholar wrote 10 pieces in this area, about 5000 researchers would have been pushing the constitutional political economy research program forward.

It bears noting that Table 3's list is somewhat more homegrown than in the other fields, as all but one of the pieces listed were written by persons with long affiliations with the public choice societies in the United States and Europe. The impact of that research, however, as in the other cases, extends well beyond public choice scholarship per se.

\footnotetext{
${ }^{5}$ Doucouliagos and Ulubaşoğlu (2008) provide a useful meta-study of the results of this enormous body of research by public choice and economic development researchers.
} 
Table 3 Public choice analysis of constitutions: a sample of influential pieces and citation numbers

Buchanan, J. M. (1949). The pure theory of government finance: A suggested approach. Journal of Political Economy, 57(6), 496-505

Buchanan, J. M., \& Tullock, G. (1962). The calculus of consent: Logical foundations of constitutional democracy. Ann Arbor, MI: University of Michigan Press

Brennan, G., \& Buchanan, J. M. (1985/2008). The reason of rules: Constitutional political economy. Cambridge, UK: Cambridge University Press

Nitzan, S., \& Paroush, J. (1982). Optimal decision rules in uncertain dichotomous choice situations. International Economic Review, 23(2), 289-297

Grier, K. B., \& Tullock, G. (1989). An empirical analysis of cross-national economic growth, 1951-1980. Journal of Monetary Economics, 24(2), 259-276

Ostrom, E. (1990). Governing the commons. Cambridge, UK: Cambridge University Press

Olson, M. (1993). Dictatorship, democracy, and development. American Political Science Review, 87(3), 567-576

Knack, S., \& Keefer, P. (1995). Institutions and economic performance: cross-country tests using alternative institutional measures. Economics and Politics, 7(3), 207-227

Mueller, D. C. (1996). Constitutional democracy. Oxford UK: Oxford University Press

Persson, T., Roland, G., \& Tabellini, G. (2000). Comparative politics and public finance. Journal of Political Economy, 108(6), 1121-1161

Total citations

\section{The forest from the trees}

This brief overview of the idea base of public choice research has stressed its self-generated nature. The "intellectual foundations" of public choice were not laid down at the outset of the research program but gradually emerged as a product of that research. This is not to say that there are no overlaps or echos between public choice research and earlier efforts, but it is to say that such overlaps and echos are more apparent in retrospect than they were as the literature emerged.

Scientific progress in public choice research is an exercise in bootstrapping, as is true of other sciences. A puzzle or lacuna overlooked by previous research is noticed by one or more thoughtful scholars and subsequent innovative work attempts to solve the puzzle or fill the gap. That elections matter implies that voting rules mattered. That voting rules must also be chosen in some way shifts attention to constitutional choices. That both policy and constitutional choices often are made or influenced by small groups of delegates or lobbyists implies that "interest" groups are important political actors. But, how do such groups form and finance themselves? Why are some groups more politically active and successful than others? Are there organizational problems that must be overcome for groups to function well? The answers and solutions often produce new puzzles-some secondary and others major-that attract further interest and innovation, and so on. Not all public choice researchers are model builders, but their intuitions about politics and political economy are grounded in the results generated by such analyses.

The supporting empirical research was for the most part consistent with positivism in that it took hypotheses to the data, rather than attempting to devise theories based on properties of the data. This is not to say that theories never were revised because of statistical, experimental or historical evidence, but that most empirical work began with hypotheses grounded in rational choice analyses of politics and political institutions. Statistical 
methods were used to determine the extent to which public choice accounted for political and economic phenomena in the real world. That it repeatedly was found to do so quite well demonstrated that the research program was more than an intellectual exercise. ${ }^{6}$

The contribution that public choice research has made to political science and economics is evident in its vocabulary. It invented many new ideas and words to go with them. Cycling problems, ideal points, median voters, voter paradoxes, electoral equilibrium, free riding, rational ignorance, Condorcet's jury theorem, rent seeking, Hobbesian dilemmas, two-level constitutional analysis and contractarian arguments were not found in mainstream work in economics or political science during the half century in which public choice emerged; nor were problems associated with autocorrelation, heteroscedasticity, multicollinearity, simultaneous equation bias or identification given much attention in mainstream political science, political philosophy or history. These and other "inside the field" problems attracted significant attention among public choice researchers, and in many cases the solutions and empirical evidence revealed new puzzles and problems that would not have been noticed without the results generated by previous generations of public choice research.

Some of the most interesting and important results in public choice "simply" made connections among the various research programs of public choice. The importance of institutionally induced equilibria for majoritarian decision-making provides a clear link between electoral and constitutional theories. The significance of the rules of the game for efforts in rent-seeking contests provides a clear connection between the constitutional and interest group theories. The importance of campaign contributions from interest groups to candidates for public office provides an obvious link between the election and interest group research programs.

Points of contact with economics, political science, philosophy, law and history are also evident, but for the most part the core findings and questions analyzed were unique to public choice research and would have been difficult — if not impossible — to have been discovered without the methodologies, focus and findings that characterized public choice research. $^{7}$

At points where public choice research reached conclusions similar to those obtained with other methodologies, it provides evidence of robustness-that one's conclusions about the world are not entirely determined by one's intellectual culture, mode of thought, or priors. Such cases provide evidence that there is an objective political world to be studied-that a science of politics is possible. In cases in which public choice analysis provides completely new or conflicting results, the importance of methodology cannot and should not be denied.

\footnotetext{
6 The same methodology also was associated with the many experimental studies of conclusions reached by public choice theorists. For early examples, see Fiorina and Plott (1978) or McKelvey and Ordeshook (1984). For recent surveys, see Kamm and Schram (2018, forthcoming).

7 This is not to say that public choice scholars were completely ignorant or disinterested in issues raised in related fields. Graduate education tended to be more interdisciplinary in the period during which public choice began. Moreover, most public choice scholars grew up in societies where electoral politics and constitutional government were stable and their histories were part of their basic education and national mythologies. Many ideas about politics and scientific methodology were "in the air", freely available for the taking, and these would naturally affect both the research questions addressed and, to some extent, judgements about the plausibility of answers and conclusions. Nonetheless, both the first generation of public choice scholars and those that followed brought their own creativity and methodologies to the ideas, data and results of previous generations of scholars, and reached conclusions through means that were substantially new and original.
} 
In retrospect, it can be argued that the broad outlines of field that came to be called public choice had become fairly clear by the early 1970s, but what it contained was still not entirely obvious, nor latent in the pioneering works. Its core results emerged gradually and incrementally as the generality and limits of the first contributions became better understood and appreciated by public choice researchers. Through such efforts, the intellectual foundation - the idea base - of public choice gradually emerged.

Unlike a tree farm, a new field of research benefits from a lack of closure. In a productive area of research, new possibilities, problems and lacunae constantly emerge and are tackled by successive generations of creative scholars. The result is a great body of loosely connected, but complementary work with a common knowledge base that cannot be attributed to a single scholar or a handful of innovators (except perhaps retrospectively). ${ }^{8}$

A new intellectual "forest" gradually emerged from the "trees", "bushes", "weeds" and "crabgrass" of insights and results produced by public choice researchers. It is an expanding intellectual ecosystem of ideas, puzzles, findings, innovators, scholars and researchers. Unlike a building, public choice does not have a permanent foundation, but one that grows richer or poorer as innovations and complementarities among its ideas and researchers encourage and sustain its development. Fortunately, new interesting puzzles are nearly as commonplace today as they were in 1970. Public choice thus remains a healthy, innovative, and expanding field of research—in large part because of its gradually strenthening and deepening intellectual foundations.

\section{References}

Ansolabehere, S., \& Snyder, J. M. (2000). Valence politics and equilibrium in spatial election models. Public Choice, 103(3-4), 327-336. [449 citations].

Arrow, K. J. (1951/2012). Social choice and individual values. New Haven, CT: Yale University Press. $[17,832$ citations $]$.

Becker, G. S. (1983). A theory of competition among pressure groups for political influence. The Quarterly Journal of Economics, 98(3), 371-400. [5,397 citations].

Black, D. (1948). On the rationale of group decision-making. Journal of Political Economy, 56(1), $23-34$. [2,586 citations].

Brennan, G., \& Buchanan, J. M. (2008). The reason of rules: Constitutional political economy. Cambridge: Cambridge University Press. [2,047 citations].

Brennan, G., \& Hamlin, A. (1998). Expressive voting and electoral equilibrium. Public Choice, 95(1-2), 149-175. [298 citations].

Buchanan, J. M. (1949). The pure theory of government finance: A suggested approach. Journal of Political Economy, 57(6), 496-505. [263 citations].

Buchanan, J. M. (1959). Positive economics, welfare economics, and political economy. Journal of Law and Economics, 2, 124-138. [475 citations].

Buchanan, J. M. (1975). The limits of liberty: Between anarchy and Leviathan. Chicago: University of Chicago Press.

\footnotetext{
${ }^{8}$ Of course, public choice did not emerge in isolation. The winds from other nearby fields may also provide stimulus for new developments in public choice or political economy. The field was affected by many ideas blown in by innovators outside public choice, for example, Samuelson's (1954) theory of public goods, Tiebout's (1956) theory of competition between governments, Oates's (1972) theory of fiscal federalism, Posner's (1973) treatise on law and economics, and North's (1991) theory of the role of institutions in economic development. However, most of the intellectual foundations of public choice are homegrown products of innovative men and women who worked in the field for many years, indeed, decades - not all of whom can be mentioned in a short paper.
} 
Buchanan, J. M., \& Tullock, G. (1962). The calculus of consent. Ann Arbor, MI: University of Michigan Press. [11,397 citations].

Congleton, R. D. (1980). Competitive process, competitive waste, and institutions. In J. M. Buchanan, R. D. Tollison, \& G. Tullock (Eds.), Toward a theory of the rent-seeking society. College Station, TX: Texas A \& M University Press. [110 citations].

Congleton, R. D. (1992). Political institutions and pollution control. The Review of Economics and Statistics, 74(3), 412-421. [469 citations].

Congleton, R. D., Grofman, B., \& Voigt, S. (2018, forthcoming). Oxford handbook of public choice. Oxford: Oxford University Press.

Congleton, R. D., \& Hillman, A. L. (2015). Companion to the political economy of rent seeking. Cheltenham: Edward Elgar Publishing.

Coughlin, P., \& Nitzan, S. (1981). Electoral outcomes with probabilistic voting and Nash social welfare maxima. Journal of Public Economics, 15(1), 113-121. [287 citations].

Cowling, K., \& Mueller, D. C. (1978). The social costs of monopoly power. The Economic Journal, 88(352), 727-748. [460 citations].

Crain, W. M., \& Miller, J. C., III. (1989). Budget process and spending growth. William. \& Mary Law Review, 31, 1021. [109 citations].

Doucouliagos, H., \& Ulubaşoğlu, M. A. (2008). Democracy and economic growth: A meta-analysis. American Journal of Political Science, 52(1), 61-83.

Downs, A. (1957). An economic theory of democracy. New York, NY: Harper and Row. [31,172 citations].

Enelow, J., \& Hinich, M. J. (1981). A new approach to voter uncertainty in the Downsian spatial model. American Journal of Political Science, 25(3), 483-493. [218 citations].

Fiorina, M. P., \& Plott, C. R. (1978). Committee decisions under majority rule: An experimental study. American Political Science Review, 72(2), 575-598. [392 citations].

Frey, B. S. (1994). Direct democracy: Politico-economic lessons from Swiss experience. The American Economic Review, 84(2), 338-342. [381 citations].

Grier, K. B., \& Tullock, G. (1989). An empirical analysis of cross-national economic growth, 19511980. Journal of Monetary Economics, 24(2), 259-276. [1,474 citations].

Grofman, B., \& Owen, G. (1986). Information pooling and group decision making. In Proceedings of the Second University of California-Irvine conference on political economy. Greenwich, CT: JAI Press.

Grofman, B., Owen, G., \& Feld, S. L. (1983). Thirteen theorems in search of the truth. Theory and Decision, 15(3), 261-278. [370 citations].

Hillman, A. L. (1982). Declining industries and political-support protectionist motives. The American Economic Review, 72(5), 1180-1187. [748 citations].

Inman, R. P., \& Rubinfeld, D. L. (1997). The political economy of federalism (Ch. 4). In D. C. Mueller (Ed.), Perspectives on public choice: A handbook. Cambridge: Cambridge University Press. [370 citations].

Johnson, M. (2014). James M. Buchanan, Chicago, and post-war public finance. Journal of the History of Economic Thought, 36(4), 479-497.

Johnson, M. (2018). Rules versus authorities. Public Choice (forthcoming).

Kamm, A., \& Schram, A. (2018, forthcoming) Experimental public choice: Elections. In R. D. Congleton, B. Grofman, \& S. Voigt (Eds.) Oxford Handbook of Public Choice. Oxford: Oxford University Press.

Kirchgässner, G. (2000). Probabilistic voting and equilibrium: An impossibility result. Public Choice, 103(1-2), 35-48.

Kirchgässner, G., \& Pommerehne, W. W. (1996). Tax harmonization and tax competition in the European Union: Lessons from Switzerland. Journal of Public Economics, 60(3), 351-371. [249 citations].

Knack, S., \& Keefer, P. (1995). Institutions and economic performance: Cross-country tests using alternative institutional measures. Economics \& Politics, 7(3), 207-227. [5,439 citations].

Krueger, A. O. (1974). The political economy of the rent-seeking society. The American Economic Review, 64(3), 291-303. [7,673 citations].

Kuhn, T. S. (1962). The structure of scientific revolutions. Chicago, IL: University of Chicago Press.

Laband, D. N., \& Sophocleus, J. P. (1992). An estimate of resource expenditures on transfer activity in the United States. The Quarterly Journal of Economics, 107(3), 959-983. [86 citations].

McChesney, F. S. (1987). Rent extraction and rent creation in the economic theory of regulation. The Journal of Legal Studies, 16(1), 101-118. [748 citations].

McKelvey, R. D. (1976). Intransitivities in multidimensional voting models and some implications for agenda control. Journal of Economic Theory, 12(3), 472-482. [1,741 citations].

McKelvey, R. D., \& Ordeshook, P. C. (1984). An experimental study of the effects of procedural rules on committee behavior. The Journal of Politics, 46(1), 182-205. [89 citations]. 
McLean, I. (1995). The first golden age of social choice. In Social choice, welfare, and ethics: Proceedings of the eighth international symposium in economic theory and econometrics (Vol. 8). Cambridge: Cambridge University Press.

McLean, Iain, \& Hewitt, Fiona (Eds.). (1994). Condorcet: foundations of social choice and political theory. Cheltenham: Edward Elgar Publishing.

Mueller, D. C. (1973). Constitutional democracy and social welfare. The Quarterly Journal of Economics, 87(1), 60-80. [81 citations].

Mueller, D. C. (1996). Constitutional democracy. Oxford: Oxford University Press. [607 citations].

Mueller, D. C. (2003). Public choice III. Cambridge: Cambridge University Press. [3,547 citations].

Murphy, K. M., Shleifer, A., \& Vishny, R. W. (1993). Why is rent-seeking so costly to growth? The American Economic Review, 83(2), 409-414. [1,679 citations].

Nitzan, S. (1991). Collective rent dissipation. The Economic Journal, 101(409), 1522-1534. [364 citations].

Nitzan, S., \& Paroush, J. (1982). Optimal decision rules in uncertain dichotomous choice situations. International Economic Review, 23(2), 289-297. [258 citations].

North, D. C. (1991). Institutions. Journal of Economic Perspectives, 5(1), 97-112.

Oates, W. E. (1972). Fiscal federalism. New York: Harcourt Brace Jovanovich, Inc.

Olson, M. (1965). The logic of collective action. Harvard Economic Studies 124. Cambridge, MA: Harvard University Press. [39,186 citations].

Olson, M. (1982). The rise and decline of nations: Economic growth, stagflation, and social rigidities. New Haven, CT: Yale University Press. [10,382 citations].

Olson, M. (1993). Dictatorship, democracy, and development. American Political Science Review, 87(3), 567-576. [3,690 citations].

Ostrom, E. (1990). Governing the commons. Cambridge: Cambridge University Press. [30,167 citations].

Peltzman, S. (1976). Toward a more general theory of regulation. The Journal of Law and Economics, 19(2), 211-240. [6,914 citations].

Persson, T., Roland, G., \& Tabellini, G. (2000). Comparative politics and public finance. Journal of Political Economy, 108(6), 1121-1161. [772 citations].

Plott, C. R. (1967). A notion of equilibrium and its possibility under majority rule. The American Economic Review, 57(4), 787-806. [1,354 citations].

Poole, K. T., \& Rosenthal, H. (1985). A spatial model for legislative roll call analysis. American Journal of Political Science, 29(2), 357-384. [857 citations].

Posner, R. A. (1973). Economic analysis of the law. Boston, MA: Little, Brown, and Co.

Rae, D. W. (1969). Decision-rules and individual values in constitutional choice. American Political Science Review, 63(1), 40-56. [478 citations].

Samuelson, P. A. (1954). The pure theory of public expenditure. The Review of Economics and Statistics, 36(4), 387-389.

Schneider, F., \& Enste, D. H. (2000). Shadow economies: Size, causes, and consequences. Journal of Economic Literature, 38(1), 77-114. [3,179 citations].

Shepsle, K. A., \& Weingast, B. R. (1981). Structure-induced equilibrium and legislative choice. Public Choice, 37(3), 503-519. [872 citations].

Shepsle, K. A., \& Weingast, B. R. (1987). The institutional foundations of committee power. American Political Science Review, 81(1), 85-104. [1,435 citations].

Stigler, G. J. (1971). The theory of economic regulation. The Bell Journal of Economics and Management Science, 2(Spring), 3-21. [11,988 citations].

Tiebout, C. M. (1956). A pure theory of local expenditures. Journal of Political Economy, 64(5), 416-424.

Tullock, G. (1967). The welfare costs of tariffs, monopolies, and theft. Economic Inquiry, 5(3), $224-232$. [4,358 citations].

Tullock, G. (1980). Efficient rent seeking. In J. M. Buchanan, R. D. Tollison, \& G. Tullock (Eds.), Toward a theory of the rent-seeking society. College Station, TX: Texas A \& M University Press. [3,149 citations].

Tullock, G. (1981). Why so much stability? Public Choice, 37(2), 189-204. [398 citations].

van Long, N., \& Vousden, N. (1987). Risk-averse rent seeking with shared rents. The Economic Journal, 97(388), 971-985. [90 citations].

von Hagen, J. (1991). A note on the empirical effectiveness of formal fiscal restraints. Journal of Public Economics, 44(2), 199-210. [412 citations].

Wagner, R. E. (1976). Revenue structure, fiscal illusion, and budgetary choice. Public Choice, 25(1), 45-61. [475 citations]. 